\title{
Level and Statistical Distribution of Thyroid Peroxidase and Thyroid Hormones in Iraqi patients with Type1 Diabetes Mellitus at Al-Karkh Side
}

\begin{abstract}
Sara S. Jabar*
Sanad B. Mohammed*

Abass R. Mahdi**

*Department of Chemistry, College of Science for Women, University of Baghdad.

**The Specialized Center for Endo Crinology and Diabetes, University Mustansiriya

Received 31/12/ 2014

Accepted 27/4/ 2015

(c) $(1)(9 \Theta$

(1) This work is licensed

under a Creative Commons Attribution-NonCommercialNoDerivatives 4.0 International Licens

Abstract:

Type 1 diabetes mellitus (T1DM) is an autoimmune disease frequently associated with autoimmune thyroid disease (AITD). The study is conducted at the Specialized Center for Endocrinology and Diabetes-Baghdad at Al-karkh side, during December 2013 up to April 2014. In this study, we investigate the prevalence of anti-thyroid peroxidase (anti-TPO) antibody in(80) type1 diabetic patients with (AITD) and (30) healthy controls .Blood samples are taken for investigation of thyroid tests by using Vitek Immunodiagnstic Assay System (VIDAS).Enzeme Linked Immunosorbent Assay (ELISA) is used to detect anti-thyroid antibody(anti-TPO). The results show that age, gender and BMI (body mass index) are similar in both groups, $\mathrm{p}>0.05$. Among 80 type 1 diabetic patients $15(18.8 \%)$ are positive. There is a highly significant difference $(\mathrm{p}<0.01)$ between TSH (Thyroid Stimulating Hormone) levels and frequently of positive and negative anti-TPO, while non significant difference ( $>0.05$ ) between T3 \&T4 and frequency of positive and negative (anti-TPO).
\end{abstract}

Key words: BMI, FBS, T3, T4, TSH, Anti-TPO.

\section{Introduction:}

Diabetes mellitus (DM) in general is simply regared to as high level of glucose in the blood (diabetes), It is a group of disruptor in the path way of glucose metabolic changes in which individual patients have high percent of glucose more than the healthy control because the pancreas does not secrete sufficient amount of (insulin) or the receptors of cells do not work and do not accept the hormone(insulin) that is produced or both of these reasons [1]. High percent of glucose level in the blood lead to increase percent the fold of urination. These symptoms, called (polyurea), and also the diabetic patients suffer from increasing in the fold drinking and need much of water (polydipsia) and also the diabetic patients feel needing to diets and feel hunger (polyphagia) [2] finally acute and complex symptoms include diabetic (ketoacidosis); (nonketotic hyperosmolar) [3] [4].

There are three main types of diabetes mellitus: 
Type1 DM: It is an autoimmune disease caused by destruction of the insulin producing $\beta$-cell in pancreas [5]. It is also referred to as insulin dependent diabetes mellitus, for short, IDDM, and juvenile diabetes [6]. The association of type 1 diabetes mellitus (T1DM) with thyroid diseases is well known, especially in the field of polyglandular autoimmune diseases. Thyroid status can influence the necessity of insulin decreased in hypothyroidism and higher in hyperthyroidism.Hypothyroidism and hyperthyroidism are the main clinical condition that affect the basal metabolic rate [7]. The term 'thyroid diabetes' is coined in the early literature to depict the influence of thyroid hormone excess in the early literature to depict the influence of nearly a century, many publication focus on the relationship between diabetes and thyroid disease, The literature concerning the effects of thyroid hormones on glucose metabolism in normal and diabetic states has been evaluated in detail [7].

Autoimmune thyroid disease (AITD) is an organ specific disorder that effects the thyroid gland. Autoimmunity against the thyroid gland results in two opposite hashimoto thyroiditis. Increased circulating activated $\mathrm{T}$ cells and thyroid specific auto antibodies occur in Graves' disease. Antibodies directed against the TSH receptor stimulate thyroid function and lead to glandular over activity[8]. The present study aims to evaluate the prevalence of thyroid pathology in patient with (T1DM).

\section{Materials and Methods}

Sample Collection

A total of 80 samples (53 females and 27 males) are collected from Iraqi diabetic patients who attend the Specialized Center for Endocrinology and Diabetes in Al-Karkh Side in Baghdad. Also 30 healthy individuals 22 females and 8 males are enrolled as a control group.
Approximately $5 \mathrm{ml}$ of human blood is collected from each individual and transfered into sterilized test tubes and allowed to clot for $30 \mathrm{~min}$ at room temperature. The sample is centrifuged for $5 \mathrm{~min}$. at $2500 \mathrm{rpm}$ and the serum is separated and stored at $\left(-20^{\circ} \mathrm{C}\right)$ for investigation of F.B.S., triiodothyronine T3, tetraiodothyroxine T4, thyroid stimulating hormone TSH, Anti-TPO (IgG) and lipid profile tests.

Laboratory Tests:

Serum is analyzed for (T3, T4 and TSH) using VIDAS (Vitek Immuno Diagnostic Assay System) instrument. Serum (Anti-TPO) is analyzed for AntiTpo by Sandwich ELISA method. Fasting serum glucose is determined by using Accu -chek active monitor,the test of lipid profile by the sea separation method technique.

\section{Results and Discussion:}

Distribution of Studied Groups according to Body Mass Index (BMI):

Regarding the subject's BMI, Table

(1) indicate no significant different at P>0.05 among redistribution of studied groups throughout the difference at of BMI classes in contrast to the studied samples. In addition to that, testing difference ratios between two independent groups shows that all classes have no significant differences at $\mathrm{P}>0.05$, and that is more reliable and successful for this study. This is so because any meaningful deviation have registered between the two studied groups should be interpreted due to studied parameters, as well as the studied groups seem to be selected from the same population in respect of BMI indeed. 
Table (1): Distribution of BMI in the Study and Control Groups with Causes correlation ship and Comparison of Significance

\begin{tabular}{|c|c|c|c|c|c|c|}
\hline \multirow{2}{*}{$\begin{array}{c}\text { BMI } \\
\text { Mean ( Kg) } \\
(\text { Controls })\end{array}$} & \multirow{2}{*}{$\begin{array}{c}\text { BMI } \\
\text { Mean ( Kg) } \\
\text { (Patients) } \\
\end{array}$} & \multirow[t]{2}{*}{ Body Mass Index } & \multirow[t]{2}{*}{ No.\& Percents } & Groups & \multicolumn{2}{|c|}{$\begin{array}{l}\text { C.S. }{ }^{(*)} \\
\text { P-value }\end{array}$} \\
\hline & & & & Patients & Control & \\
\hline \multirow{3}{*}{0} & \multirow{3}{*}{16.66} & \multirow{3}{*}{ Under weight } & No. & 3 & 0 & \multirow{12}{*}{$\begin{array}{c}\text { C.C. }=0.174 \\
\mathrm{P}=0.329 \\
\text { NS }\end{array}$} \\
\hline & & & $\%$ Body Mass Index & $100 \%$ & $0.0 \%$ & \\
\hline & & & $\%$ Groups & $3.8 \%$ & $0.0 \%$ & \\
\hline \multirow{3}{*}{2.22} & \multirow{3}{*}{27.48} & \multirow{3}{*}{ Normal weight } & No. & 37 & 10 & \\
\hline & & & $\%$ Body Mass Index & $78.7 \%$ & $21.3 \%$ & \\
\hline & & & $\%$ Groups & $46.3 \%$ & $33.3 \%$ & \\
\hline \multirow{3}{*}{26.90} & \multirow{3}{*}{26.36} & \multirow{3}{*}{ Overweight } & No. & 25 & 11 & \\
\hline & & & $\%$ Body Mass Index & $69.4 \%$ & $30.6 \%$ & \\
\hline & & & $\%$ Groups & $31.3 \%$ & $36.7 \%$ & \\
\hline \multirow{3}{*}{63.55} & \multirow{3}{*}{32.93} & \multirow{3}{*}{ Obese } & No. & 15 & 9 & \\
\hline & & & $\%$ Body Mass Index & $62.5 \%$ & $37.5 \%$ & \\
\hline & & & $\%$ Groups & $18.8 \%$ & $30.0 \%$ & \\
\hline
\end{tabular}

${ }^{(*)}$ NS: Non Sig. at P>0.05: Contingency Coefficient.

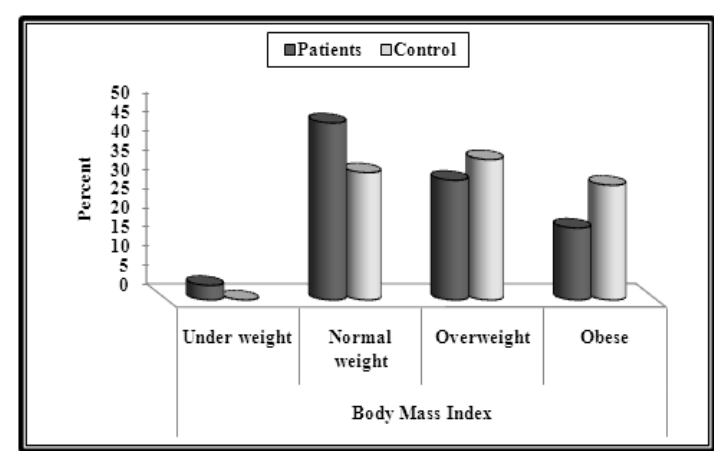

Fig. (1): Cluster Bar Chart for the Observed Frequencies of Body Mass Index's Classes of The Studied Groups

Data demonstrated on Table(1) and Figure (1) represent the distribution of patients according to BMI in comparison with the control group. The Table shows that the majority of patient with T1DM were at normal weight $37(87.7 \%)$, while over weight is found $25(69.4 \%)$ and obese $15(62.5 \%)$, while underweight $3(100 \%)$. A non significant difference is found between the patients when compared with that of the control group $(p>0.05 \%)$. There is no difference between the patients with T1D and control groups according to BMI. This result matches Hesham El-Hefnawy et.al, 2004[9], and Erdogan et.al, 2010 Who had stated that the distribution does not differ between studied groups according to BMI [10].
Distribution of Fasting Blood Sugar (F.B.S) for Patients with Type1 DM and Controls Group

These results obtained from Table(2) and Figure (2) show the distribution of patients and control groups according to FBS concentration which showed that a highly significant difference is found in FBS concentration in patient group, $(p<0.01)$ when compared with the control group. Because of the metabolic rate increase in such a way, the lipids combustion due in the age between (2030) year in type 1 diabetes mellitus. Also the insulin obscene removed the insulin organization in type 1 diabetes mellitus. These results agree with Bluestone (2010)(34).

\section{Distribution of Fasting Blood Sugar (F.B.S.) for Patients with Type1 DM and Controls Group:}

The relationship between redistribution of "F.B.S." test according to (Normal and Abnormal) outcomes in patients group and different classes of BMI is shown on Table (2).

The results show that a highly significant correlation are accounted at $\mathrm{P}<0.01$, since all of the studied patients with respect to uncontrolled "F.B.S." 
Table (2): Distribution of FBS in the Study and Control Group

\begin{tabular}{|c|c|c|c|c|c|c|}
\hline \multicolumn{2}{|c|}{ F.B.S. (mean \pm SD) $\mathrm{Mg} / \mathrm{L}$} & \multirow{2}{*}{ Response } & \multirow{2}{*}{ No. \& Percents } & \multicolumn{2}{|c|}{ Groups } & \multirow{2}{*}{$\begin{array}{l}\text { C.S. } .^{(*)} \\
\text { P-value }\end{array}$} \\
\hline Patients & Control & & & Patients & Control & \\
\hline \multirow{6}{*}{$226.1 \pm 111.5$} & \multirow{6}{*}{$93.5 \pm 11.9$} & \multirow{3}{*}{ Normal } & No. & 8 & 28 & \multirow{6}{*}{$\begin{array}{c}\text { C.C. }=0.620 \\
P=0.000 \\
\text { HS }\end{array}$} \\
\hline & & & $\%$ F.B.S & $22.2 \%$ & $77.8 \%$ & \\
\hline & & & $\%$ Groups & $10.0 \%$ & $93.3 \%$ & \\
\hline & & \multirow{3}{*}{ Abnormal } & No. & 72 & 2 & \\
\hline & & & $\%$ F.B.S & $97.3 \%$ & $2.7 \%$ & \\
\hline & & & $\%$ Groups & $90.0 \%$ & $6.7 \%$ & \\
\hline
\end{tabular}

HS:: Highly Significant at P<0.01; C.C. : Contingency Coefficient.

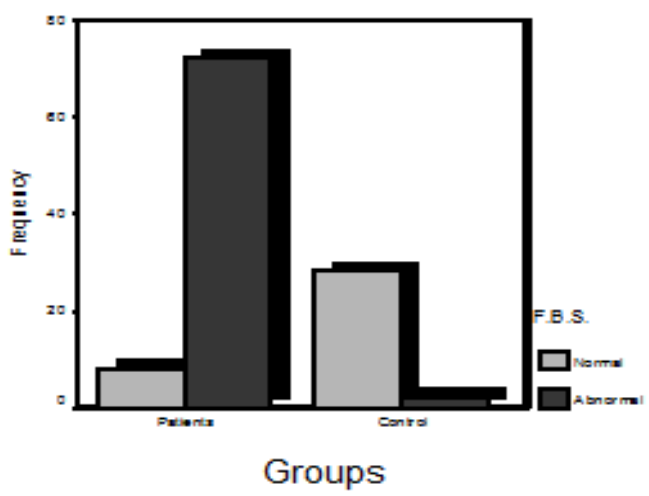

Fig.(2) Cluster Bar Charts Distribution of Studied Groups According to FBS.

Results obtained from Table and Figure (2) showed the distribution of patients and control groups according to FBS concentration. The show that $72(97 \%)$ of patients group have an abnormal FBS, and $8(22.2 \%)$ have normal FBS. A highly significant difference in the FBS concentration in the patient group, when compared with FBS concentration of the control group. These results are compatible with the study carried out in Iraq in 2000, which have out found that the FBS is highly significant in diabetic compared to the control group[11]. Diabetic patients have a higher level of blood sugar compared with non diabetic subjects. This variation is absence or resistance of insulin [12]. These results are compatible with the study carried out in Iraq by Hussein 2012 who found that the FBS were significantly higher in diabetic patients when compared to control group [13] .Diabetic patients who have higher level of blood sugar compared with non diabetic subjects this variation is due to obscene or resistance of insulin. These findings are in good agreement with the other study by Muhammad Hanfi in Egypt in 2011[14].

Table (3): Distribution of BMI Classes in Patients Group with their Relationship

\begin{tabular}{|c|c|c|c|c|c|c|}
\hline \multicolumn{2}{|c|}{$\begin{array}{c}\text { F.B.S. }(\text { mean } \pm \text { SD) } \\
\mathrm{Mg} / \mathrm{L}\end{array}$} & \multirow{2}{*}{$\begin{array}{c}\text { Body Mass } \\
\text { Index }\end{array}$} & \multirow[t]{2}{*}{ No.\& Percents } & \multicolumn{2}{|c|}{ F.B.S. } & \multirow{2}{*}{$\begin{array}{l}\text { C.S. }{ }^{(*)} \\
\text { P-value }\end{array}$} \\
\hline Patient & Control & & & Controlled & Uncontrolled & \\
\hline \multirow{12}{*}{$226.1 \pm 111.5$} & \multirow{12}{*}{$93.5 \pm 11.9$} & \multirow{3}{*}{$\begin{array}{l}\text { Under } \\
\text { weight }\end{array}$} & No. & 2 & 1 & \multirow{12}{*}{$\begin{array}{c}\text { C.C. }=0.416 \\
\mathrm{P}=0.001 \\
\mathrm{HS}^{(*)} \mathrm{HS}: \text { Highly Sig } \\
\text { at } \mathrm{P}<0.01: \\
\text { Contingency } \\
\text { Coefficient. }\end{array}$} \\
\hline & & & $\begin{array}{c}\% \text { Body Mass } \\
\text { Index }\end{array}$ & $66.7 \%$ & $33.3 \%$ & \\
\hline & & & $\%$ Groups & $25.0 \%$ & $1.4 \%$ & \\
\hline & & \multirow{3}{*}{$\begin{array}{l}\text { Normal } \\
\text { weight }\end{array}$} & No. & 6 & 31 & \\
\hline & & & $\begin{array}{c}\% \text { Body Mass } \\
\text { Index }\end{array}$ & $16.2 \%$ & $83.8 \%$ & \\
\hline & & & $\%$ Groups & $75.0 \%$ & $43.1 \%$ & \\
\hline & & \multirow{3}{*}{ Overweight } & No. & 0 & 25 & \\
\hline & & & $\begin{array}{c}\% \text { Body Mass } \\
\text { Index }\end{array}$ & $0.0 \%$ & $100 \%$ & \\
\hline & & & $\%$ Groups & $0.0 \%$ & $34.7 \%$ & \\
\hline & & \multirow{3}{*}{ Obese } & No. & 0 & 15 & \\
\hline & & & $\begin{array}{c}\% \text { Body Mass } \\
\text { Index }\end{array}$ & $0.0 \%$ & $100 \%$ & \\
\hline & & & \% Groups & $0.0 \%$ & $20.8 \%$ & \\
\hline
\end{tabular}

${ }^{(*)}$ HS: Highly significant at $\mathrm{P}<0.01$ : Contingency Coefficient. 


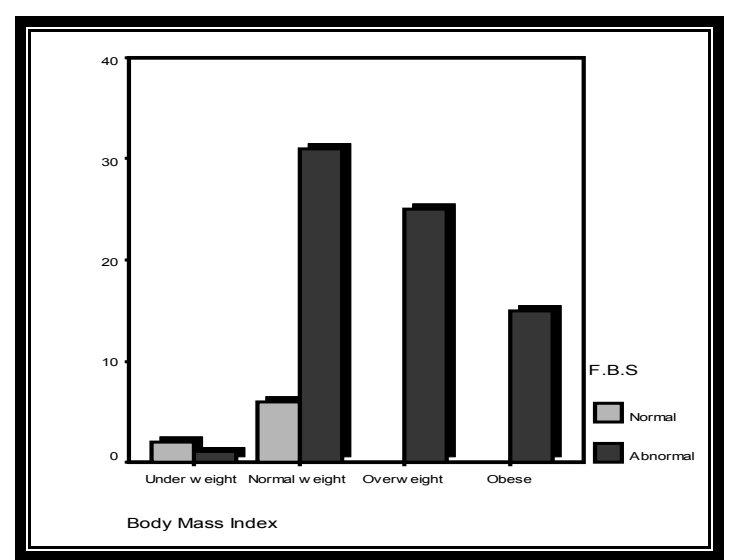

Fig. (3) The Observed F.B.S Frequencies with Respect to BMI Classes in the Studied Groups.

The results obtained from Table(3) and Figure (3) showed the distribution of patients and control groups according to FBS concentration and BMI. They show that a highly significant difference is found in FBS concentration in patient group, $(\mathrm{p}<0.01)$ when compared with control group. Because of the metabolic rate increase in such a way the lipids combustion due in the age between (2030) year in type 1 diabetes mellitus. Also the insulin obscene removes the insulin organization in type1 diabetes mellitus. These results agree with Bluestone (2010)[15].

Level and Distribution of Serum AntiThyroidperoxidase (TPO) IgG Antibody Concentration for Patients with Type1 DM and Controls Group: Table and Figure (4) represent the level and distribution of Anti-Tpo in the patiants and control groups. These results show that $15(18.8 \%)$ of patients group have an abnormal and $65(68.4 \%)$ had normal one .A highly significant difference $(\mathrm{p}<0.01)$ were found when we compared type1 diabetic patients with the healthy control group according to positivite anti - TPO (IgG) antibody.

Table (4): Level and Distribution of Anti- Thyroidperoxidase (TPO) IgG Antibody Concentration in the Patients and Control Groups with Causes Correlation ship and Comparison Significance

\begin{tabular}{|c|c|c|c|c|c|c|c|}
\hline \multicolumn{2}{|c|}{ Anti- TPO (mean \pm SD) $\mathrm{Mg} / \mathrm{L}$} & \multirow[t]{2}{*}{ Parameter } & \multirow[t]{2}{*}{ Response } & \multirow[t]{2}{*}{ No.\&Percents } & \multicolumn{2}{|c|}{ Groups } & \multirow[t]{2}{*}{ C.S. ${ }^{\left({ }^{*}\right)} \mathrm{P}$-value } \\
\hline Patient & control & & & & Patients & Control & \\
\hline \multirow{6}{*}{$53.5 \pm 110.3$} & \multirow{6}{*}{$15.2 \pm 4.5$} & \multirow{6}{*}{ Anti-TPO } & \multirow{3}{*}{ Normal } & No. & 65 & 30 & \multirow{6}{*}{$\begin{array}{c}\text { C.C. }=0.236 \\
\mathrm{P}=0.0107 \\
\mathrm{~S}\end{array}$} \\
\hline & & & & $\%$ F.B.S & $68.4 \%$ & $31.6 \%$ & \\
\hline & & & & $\%$ Groups & $81.3 \%$ & $100 \%$ & \\
\hline & & & \multirow{3}{*}{ Abnormal } & No. & 15 & 0 & \\
\hline & & & & $\%$ F.B.S & $100 \%$ & $0.0 \%$ & \\
\hline & & & & $\%$ Groups & $18.8 \%$ & $0.0 \%$ & \\
\hline
\end{tabular}

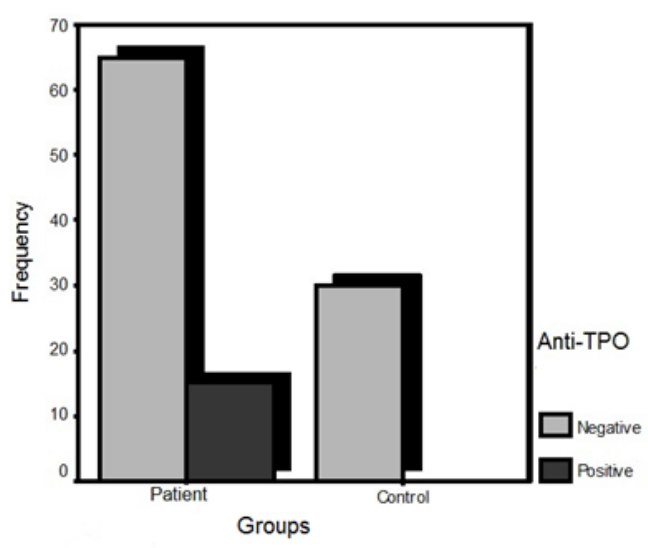

Fig. (4): Cluster Bar Chart for the Distribution of Normal and Abnormal (Anti-TPO) in the Patients and Control Groups.
Antithyroid antibodies (anti-TPO) are considered as anti -thyroid antibodies directed to the thyroid follicular microsomes, i.e, antiperoxidase. TPO is a membrane -bound, glycosylated hemoprotien that plays a key role in thyroid hormone synthesis by catalyzing both the iodotyrosyl residues to generate the thyroid hormones T3 and T4.The results above are in agreement with those made in Egypt in 2004, where found a highly significant difference between both groups [9]. This study also agrees with former study conducted by Faranak Sharifi et.al, 2007 [16].These results are compatible with Aaron 
Hanukoglu et.al, 2003 [17] ,H.Moayeri et.al,2004 [18], and Erdogan et.al,2010 [10], who have stated the significant increase in the value of anti-TPO in type1 DM when compared to controls.

Level and Distribution of T3, T4, TSH of Patients with Type1 DM and Control Groups:

Table (5) shows the distribution T3, T4, TSH of patients and apparently healthy control group who are involved in this study. The data show that distribution of T3 concentration among diabetic patients, with highly significant differences $(\mathrm{p}<0.01)$ when compared with control group. Furthermore, we have found statistically significant differences between studied groups according to $\mathrm{T} 4$ concentration $(\mathrm{p}=0.042)$. Finally, Thyroid function test in the study population is depicted in Table(5). The total abnormal upper limit of TSH level among the patients with diabetes is $16(20 \%)$ and the total patients with normal TSH level are 64(80\%). Highly statistically was found significant differences between studied groups according to TSH concentration $\mathrm{p}<0.01$.

Table (5): Levels and distribution of thyroid functional hormones according to Studied Groups with Their Relationship

\begin{tabular}{|c|c|c|c|c|c|c|c|c|}
\hline \multirow{2}{*}{ Parameters } & \multirow{2}{*}{ Patients } & \multirow{2}{*}{ Control } & \multirow{2}{*}{ Parameter } & \multirow{2}{*}{ Response } & \multirow{2}{*}{ No.\& Percents } & \multicolumn{2}{|c|}{ Groups } & \multirow{2}{*}{$\begin{array}{l}\text { C.S. } .^{(*)} \\
\text { P-value }\end{array}$} \\
\hline & & & & & & Patients & Control & \\
\hline \multirow{6}{*}{$\begin{array}{c}\mathrm{T} 3(\mathrm{mean} \pm \mathrm{SD}) \\
\mathrm{Mg} / \mathrm{L}\end{array}$} & \multirow{6}{*}{$1.57 \pm 0.7$} & \multirow{6}{*}{$1.78 \pm 0.3$} & \multirow{6}{*}{$\mathrm{T} 3$} & \multirow{3}{*}{ Normal } & No. & 73 & 30 & \multirow{6}{*}{$\begin{array}{c}\text { C.C. }=0.219 \\
\mathrm{P}=0.019 \\
\mathrm{~S}\end{array}$} \\
\hline & & & & & $\% \mathrm{~T} 3$ & $69.1 \%$ & $39.9 \%$ & \\
\hline & & & & & $\%$ Groups & $83.3 \%$ & $100 \%$ & \\
\hline & & & & \multirow{3}{*}{ Abnormal } & No. & 13 & 0 & \\
\hline & & & & & $\%$ T3 & $100 \%$ & $0.0 \%$ & \\
\hline & & & & & $\%$ Groups & $16.3 \%$ & $0.0 \%$ & \\
\hline \multirow{6}{*}{$\begin{array}{c}\mathrm{T} 4(\text { mean } \pm \mathrm{SD}) \\
\mathrm{Mg} / \mathrm{L}\end{array}$} & \multirow{6}{*}{$83.8 \pm 21.5$} & \multirow{6}{*}{$73.7 \pm 1.2$} & \multirow{6}{*}{$\mathrm{T} 4$} & \multirow{3}{*}{ Normal } & No. & 70 & 30 & \multirow{6}{*}{$\begin{array}{c}\text { C.C. }=0.190 \\
\mathrm{P}=0.042 \\
\mathrm{~S}\end{array}$} \\
\hline & & & & & $\% \mathrm{~T} 4$ & $70.0 \%$ & $30.0 \%$ & \\
\hline & & & & & $\%$ Groups & $87.5 \%$ & $100 \%$ & \\
\hline & & & & \multirow{3}{*}{ Abnormal } & No. & 10 & 0 & \\
\hline & & & & & $\% \mathrm{~T} 4$ & $100 \%$ & $0.0 \%$ & \\
\hline & & & & & $\%$ Groups & $12.5 \%$ & $0.0 \%$ & \\
\hline \multirow{6}{*}{$\begin{array}{c}\mathrm{TSH}(\operatorname{mean} \pm \mathrm{SD}) \\
\mathrm{Mg} / \mathrm{L}\end{array}$} & \multirow{6}{*}{$2.98 \pm 3.7$} & \multirow{6}{*}{$2.28 \pm 1.2$} & \multirow{6}{*}{ TSH } & \multirow{3}{*}{ Normal } & No. & 64 & 30 & \multirow{6}{*}{$\begin{array}{c}\text { C.C. }=0.245 \\
\mathrm{P}=0.008 \\
\text { HS }\end{array}$} \\
\hline & & & & & $\%$ TSH & $68.1 \%$ & $31.9 \%$ & \\
\hline & & & & & $\%$ Groups & $80 \%$ & $100 \%$ & \\
\hline & & & & \multirow{3}{*}{ Abnormal } & No. & 16 & 0 & \\
\hline & & & & & $\% \mathrm{TSH}$ & $100 \%$ & $0.0 \%$ & \\
\hline & & & & & $\%$ Groups & $20 \%$ & $0.0 \%$ & \\
\hline
\end{tabular}

HS: Highly Significant at $\mathrm{P}<0.01$ Contingency Coefficient

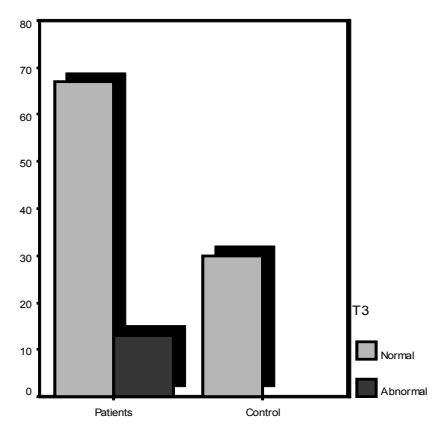

Groups

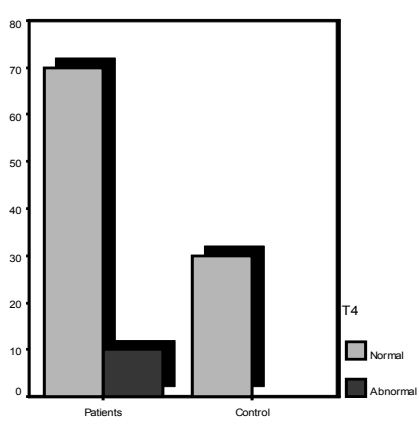

Groups

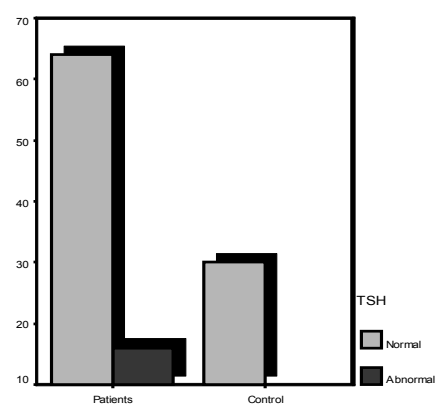

Groups

Fig. (5): Cluster Bar charts for the Observed Frequencies of "Thyroid Functional hormones: T3, T4, and TSH" in the Studied Groups. 
In the present study can state that the studied parameters (Thyroid Functional hormones: T3, T4, and TSH).This is so because emphasize the actual relationships between the diabetes mellitus and thyroid disorders, since diabetes mellitus patient's numbers whom had morbidity registration with thyroid disease, are accounted as significant differences in comparison to the control group.

In the current study, the TSH value is inversely related to the total $\mathrm{T} 4$ value. The normal results for TSH level in patients are under treatment. These results support the use of serum TSH level as the best test to detect abnormal thyroid function. TSH is one of the most commonly requested blood tests; it is a very sensitive indicator of primary hypothyroidism. The present results are nearly compatible with a study made in Nigeria in 2007 [19], which have found out that there is no difference regarding T3 \& TSH levels between both groups. There was no difference between diabetic and non diabetic patients for distribution of total T4. This result matches Magda Osman 2010[19], and Ditta et.al, 2001[20], and the one performed in Iraq in 2010 by ALOmairi[16]. It is also nearly in agreement with another study made in India in 2008 by Palanisamy et.al[21].

\section{References:}

[1]Lippincott Williams and Wilkins. 2011. Modifocous Guidebook on type 1 diabetes mellitus, USA; Section:2, 15.

[2]Charels, B. 2009. Books Clinical pediatric Endocrinology. C 18:458462.

[3]Kitabchi, A. E.; Umpierrez, G. E.; Miles, J. M.; Fisher, J. N. 2009. Hyperglycemic crises in adult patients with diabetes.. Care 32 (7): 1335-43.

[4]Shoback, edited by David G. Gardner, Dolores. 2011. Greenspan's basic \& clinical endocrinology (9th ed.). New York: McGraw-Hill Medical. Chapter 17. 162243-8

[5]Susane Sh., Julia Pu., Jarno Ho., Merja Ro., Jorma I. 1., Hanna H.o., Johnny L. u., Outi Va. 2010. Decreased in vitro type 1 immune response against Coxsackie virus B4 in children with type 1 diabetes. 59(10).

[6]Leonid, and poretsky. 2010. Principles of Diabetes Mellitus. 181220.

[7]Chistiakov, D. A. and Turakulov, R. I. 2003. CTLA-4 and its role in autoimmune thyroid disease. J.M.E. 31:21-36

[8]Idriceanu, J., Graur M., Preda, C., Vasiliu, I., Balcan, R., Ungureanu, M., Cristea, C. and Vulpoi, C. 2011. Thyroid pathology in patients with type 1 diabetes mellitus.26 P439

[9]El-Hefnawy, H., Bassyouni, A. and Abdel-Karrem, M.. 2014. Evaluation of subclinical thyroidities among Egyption Diabetic patients, 63.

[10] Erdogan, S. and Serap, k. 2010. Seroprevalence of Autoimmune Thyroid itis and Celiac Disease in Children with Insulin - dependent Diabetes Mellitus in the Thrace region of Turkey.

[11] Al-Naama, L. M., Kadhim, M. and Al-Abound M.S. 2000 .Lipid profile in Children with Insulin Dependent Diabetes Mellitus.

[12] Elbagir, M. N.; Eltom, M. A.; Elmahadi, E. M.; Kadam, I. M. and Berne, C. 1996. Apopulation based study of the prevalence of diabetes and impaired glucosetolerance in adults in norther $\mathrm{n}$ Sudan.J.Diabetes Care. 19(10):1126-8.

[13] Hussein, N. S. 2012. Autoimmune thyroid Diseases in Diabetic patients. M.S.c thesis College of Health and medical Technology, Baghdad, 20.

[14] Hanif S. M.; Barkat, A.; Shand A. S. 2011. Comparative study on 
lipid changen in Glycemic Unecontrolled Diabetes Type 2. J. Diabetes care. 20(10):8.

[15] Bluestone J. A.; Herold, K. and Eisenbarth G. 2010. Genetics, pathogenesis and clinical interventions in type 1 diabetes. Nature 464 (7293): 1293-1300.

[16] Al-Omairi, A. 2010. Association of Hypothyroidism with resistance, Master of technology in medical laboratory science technology collage, Baghdad. 84.

[17] Doing, C.; Udon, A. E. and Etukudon, M. E. 2007. Evaluation of thyroid function in Diabetes Mellitus in Calabar, Nigeria. 22(2):74-78.

[18] Moayeri, H. and Rabbani, A. 2004. Prevalence of autoantibodies to thyroid peroxidase and autoimmune thyroid disease in type 1 diabetes mellitus, 20(11):28.

[19] Magada, O. and Abdullah, A. 2010. 'Evalution of Blood Glucose and thyroid Function In Sudanese Diabetic patients. Egypt Acad .J. biology, 12(16):15-30.

[20] Ditta, A. and Tayyab, M. 2001. significance of Thyrotrophin and Thyroxine Estimation In Type 1 Diabetes.

[21] Palanisamy, p.; Govindaswamy, B. and Ganesan, S. 2008. Thyroid Dysfunction in Diabetic /Non Diabetic population. (J. of Endocrinology), 18:111.

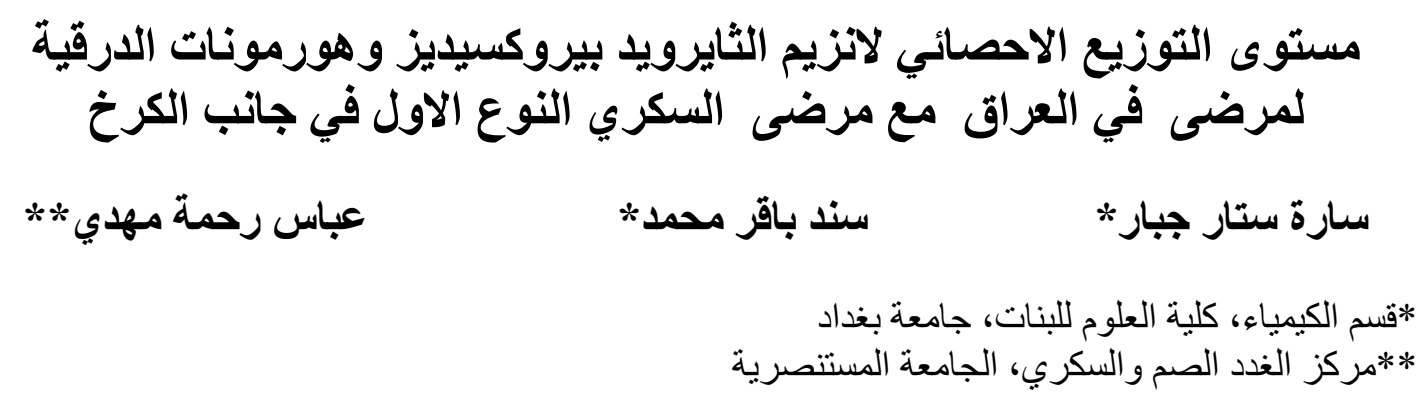

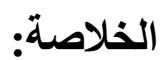

مرض السكري النوع الاول ذاتي مناعي يتميز بنقص الأنسولين المطلق نتيجة تحطم خلايا البنكرياس نوع بيتا

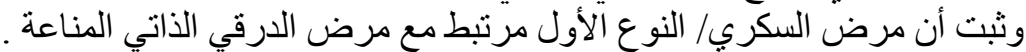

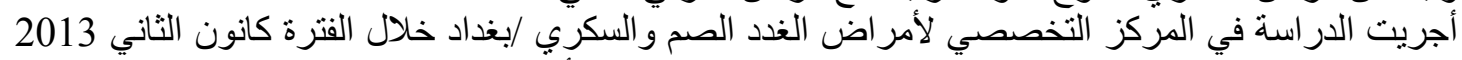

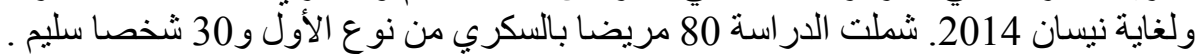

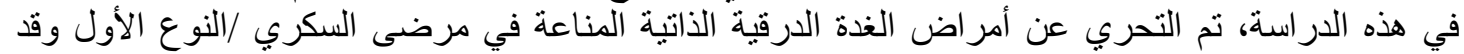

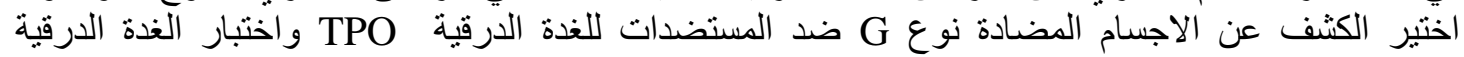

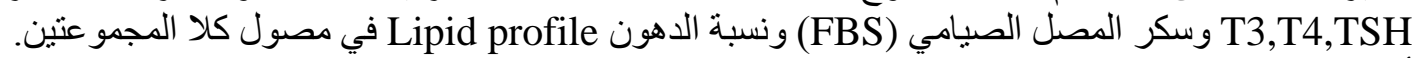

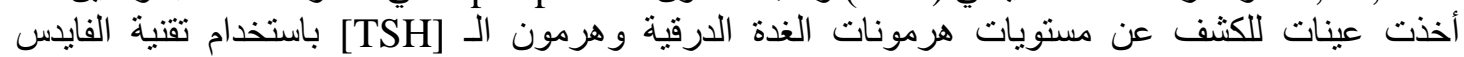

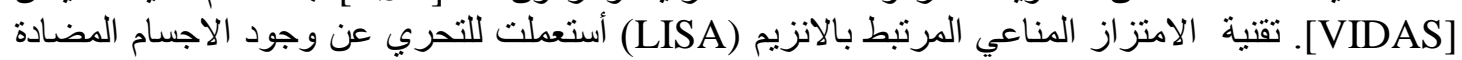
نوع [G] ضد مستضدات الغدة الدرقية (TPO).

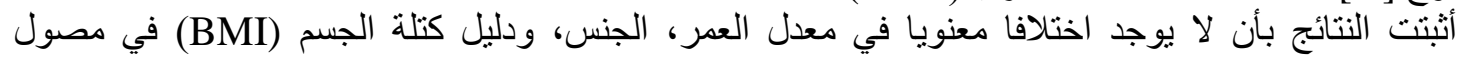

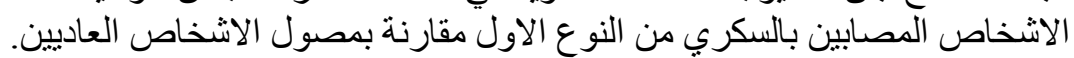

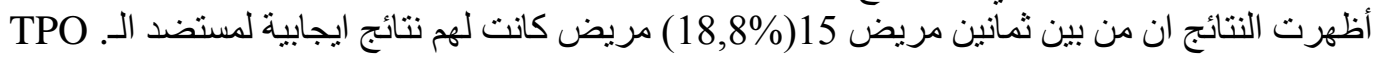

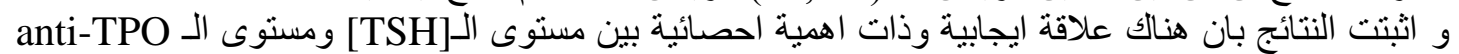

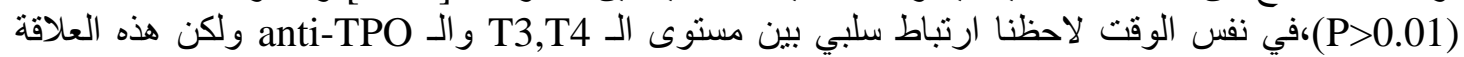

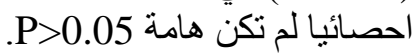

الكلمات المفتاحية: منسب كتلة الجسم، هرمون ثلاثي اليود، هرمون رباعي اليود، هرمون المحفز للارقية، مضاد أنزيم الدر اقات. 